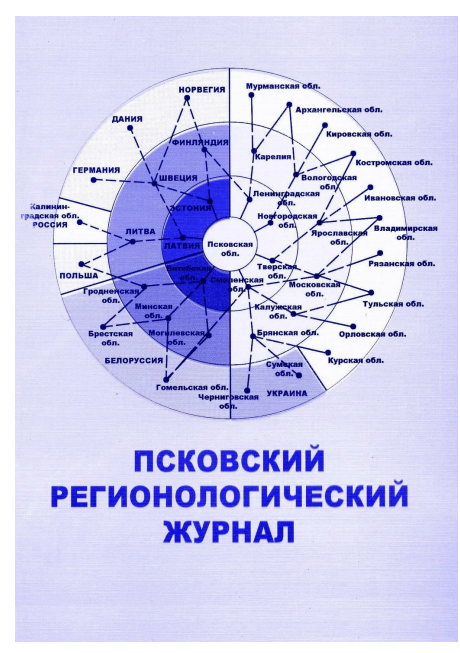

Псковский регионологический журнал. 2013-2023

ISSN 2219--7931

URL - $\underline{\text { http://prj.pskgu.ru }}$

Все права защищены

Выпуск 1 (45) Том . 2021

\title{
The involvement of the region into integration processes: tourism projects (case of the Republic of Karelia)
}

\section{Кондратьева Светлана Викторовна}

Institute of Economics of the Karelian Research Centre of the Russian Academy of

Sciences

Russian Federation, Petrozavodsk

\section{Аннотация}

International project activity is one of the tools for establishment of stable networks of interaction between countries, for integration of the territories of neighboring states. The article aims to determine the involvement of the region into integration processes on the basis of international tourism-oriented project activities in the municipal context. The research information base includes a vast array of information on the practice of international project activities of the Republic of Karelia in the field of tourism for the period 1990-2020 (about 90 projects under five Programs) in the context of 18 municipalities of the region. The work calculated median indicators. The study used the analysis of statistical and analytical information, content analysis of strategic documents, methods of generalization, comparison and analogies..The author proposed an approach that allows to recognize a comprehensive vision of the level of involvement of the region in the integration processes in the municipal context as well as to formulate ecommendations for enhancing this sphere of activity. Two main periods of development of international project activities in the field of tourism in the region are defined. The typology of involvement of municipalities of the Republic of Karelia in integration processes based on aggregate indicators of project activity is proposed. The strengthening of the involvement of the Republic of Karelia as a whole and individual municipalities in the integration processes in the field of tourism is substantiated. The results of this study can be used by regional authorities when making managerial decisions in tourism area. The outcomes of the research have scientific and practical significance for scholars who 
research the issues of the development of regional tourism as well as for representatives of tourism business.

Ключевые слова: international projects, the Republic of Karelia, involvement in integration processes, municipality, tourism

Дата публикации: 19.05.2021

Источник финансирования:

The study was carried out within the framework of the budget assignment of the Institute of Economics of the Karelian Scientific Center of the Russian Academy of Sciences № AAAA-A19-11901099008

Ссылка для цитирования:

Кондратьева С. В. The involvement of the region into integration processes: tourism projects (case of the Republic of Karelia) // Псковский регионологический журнал. - 2021. - Выпуск 1 (45) С. 62-76. URL: https://prj.pskgu.ru/s221979310013150-8-1/. DOI: 10.37490/S221979310013150-8

1 Introduction. International project activities seem to be one of the tools for establishing stable networks of interaction between countries, integrating the territories of neighboring states. The problem of international cooperation in the field of tourism (especially in the borderlands) is one of the topical areas of scientific research.

2 The purpose of the article is to determine the involvement of the region in the integration processes on the basis of international tourism-oriented project activities in the municipal context.

$3 \quad$ Literature review. In modern conditions, with the growing importance of cross-border cooperation, international project activities seem to be one of the tools for establishing sustainable networks of interaction between countries, spatial development and integration of border territories of neighboring states. The implementation of projects in the field of tourism is one of the directions for the development of cross-border cooperation between regions on different sides of the state border.

4 The transformation of the socio-economic space of Russia and its inclusion in integration processes since the end of the 20th century, a change in attitudes towards tourism at the level of government - business - society, as well as the possibility of developing economic activities in the borderlands (including tourism and recreation) served as a prerequisite for the implementation of international projects in the sphere of tourism in the border regions of the state.

5 Since the 1990's to the present time, the problem of international cooperation in the field of tourism (especially in the borderlands) is one of the topical areas of scientific research. To date, the scientific community has accumulated a significant theoretical and practical groundwork that reveals the 
possibilities and prospects, general trends, as well as the specifics of the implementation of international projects in the field of tourism in the borderlands. The works of Russian scientists on this topic began to appear only at the beginning of the 21st century, which is due to geopolitical, socio-economic and other factors of the development of the state in historical retrospect.

6 Thus, the work of the researcher C.-M. Bâtea (Babes-Bolai University, Romania) proves the link between the establishment of cross-border relations and the development of tourism based on the analysis of ten implemented tourism projects within the framework of the Hungary-Romania cross-border cooperation program for the period 2007-2013. [7]. An assessment of the implementation of cross-border projects implemented with the support of the INTERREG VA Program "Poland - Slovakia 2014-2020" is presented in the collective work of Brazilian and Polish scientists [18]. Much attention is paid to the problem of creating cross-border tourist areas in the Baltic Sea region. As an example, we can cite the works: researchers of Lund University (Sweden) on the development of cross-border tourism within the framework of the INTERREG III Program [16], scientists of the Polish Academy of Sciences on the possibilities of tourism in crossborder integration [23]. It is necessary to emphasize the deep study of the issues of cross-border interaction within the framework of the programs of cross-border cooperation in the field of tourism in the Russian-Polish-Lithuanian border area by scientists of the Baltic Federal University named after I. Kant (Kaliningrad) [10; eleven; 25]. Special attention should be paid to the focus on the problems of crossborder cooperation and the activities of Euroregions in the North-West of Russia in the field of tourism $[1 ; 17 ; 22]$, the development of cross-border tourist and recreational regions $[14]$.

7 One of the topical areas of research is the design and development of crossborder tourist routes in the framework of the implementation of international projects. These routes are considered as one of the directions of diversification of the tourist product and the integration of border regions of neighboring states, stages on the way of the formation of cross-border tourist territories [21]. It should be noted a joint study of scientists from Finland and the UK, revealing the problem of transfer of knowledge and innovations in the Russian-Finnish borderland within the framework of the implementation of international projects in the field of tourism [13].

$8 \quad$ Turning to the research of international cooperation in the field of tourism in the Karelian section of the Russian-Finnish borderland (between the Republic of Karelia and Finland), it should be noted that the existing work largely reflects the generalization of the results of one or several international projects, including tourist routes $[3 ; 15 ; 19]$. Other studies focus on the analysis of opportunities for the development of certain types of tourism on the territory of the Republic of Karelia based on the implementation of international projects [8; nine; $12 ; 23]$. Special attention should be paid to the work of NM Mezhevich [1], which focuses on the problems of cross-border cooperation and the activities of Euroregions in the North-West of Russia [1], which reveals the practice of individual projects in the tourism sector in the Russian-Finnish border area. 
Publication of the State Committee for Physical Culture, Sports and Tourism (currently the Department of Tourism of the Republic of Karelia) in the early 2000's is one of the first representations of international project activities in the field of tourism in the Republic of Karelia [6]. Thus, the existing developments are rather fragmentary, not allowing to fully systematize the accumulated regional experience in the field of tourism and assess the involvement of the Republic of Karelia in the integration processes on the basis of international projects. This work aims to close the gap. To achieve the goal set in the article, the following tasks were consistently solved: a vast array of information on the practice of implementing international tourism projects in the Republic of Karelia for the period 1990-2020 was generalized and systematized; the periods of development of international project activities in the region are highlighted; analyzed the participation of municipalities in the implementation of international tourism projects on the basis of aggregate quantitative indicators; the typology of the involvement of the Republic of Karelia in the integration processes in the municipal context is proposed.

10 For the study, the border region of the North-West of Russia was selected the Republic of Karelia (region), which has the longest land border with the EU (the Karelian section of the Russian-Finnish state border is more than $700 \mathrm{~km}$ or almost half of the land border between the $\mathbf{E U}$ and the Russian Federation) and is located at the intersection of several axes European integration (Barents region and Baltic region).

$11 \quad$ Materials and methods. 18 municipal districts of the Republic of Karelia were used as a model research site. For the first time, the work summarized and systematized a vast array of information on the practice of international project activities of the border region in the field of tourism for the period 1990-2020. About 90 international projects supported by various Programs (TACIS, INTERREG, other Programs, ENPI CBC Karelia, CBC ENP Karelia) have been analyzed for the study period 1990-2020. in the municipal context.

12 The work is based on data from open Internet sources of the Cross-Border Cooperation Programs, materials from the official Internet portal of the Republic of Karelia, strategic documents on the development of international and crossborder cooperation of the Republic of Karelia, scientific developments of Russian and foreign scientists on the issues under study, official websites of international projects in the field of tourism. The study used the analysis of statistical and analytical information, content analysis of strategic documents, methods of generalization, comparison and analogies.

13 The paper proposes and tested an approach to determining the level of involvement of the region in integration processes on the basis of international tourism-oriented project activities in the municipal context, which makes it possible to form a comprehensive understanding of the ongoing processes, to develop a typology to enhance the participation of territories (at the regional and municipal levels) in international projects - instruments for the development of tourism and attracting additional sources of financing. 
As the limitations of this study, it is necessary to point out that the systematization of international projects in the tourism sector cannot be exhaustive due to a number of objective reasons. Firstly, a number of projects are not directly related to this area of economic activity, but the results of their implementation can have a significant impact on the development of regional tourism and recreation. As an example, one can cite large infrastructure projects aimed at the development of international automobile checkpoints on the Karelian section of the RussianFinnish state border. Secondly, it is necessary to indicate the lack of information on a number of projects in open sources. Thirdly, the organizations of the region are implementing various projects with foreign partners to a greater or lesser extent related to tourism, the funding of which may be insignificant, but significant for the development of enterprises' activities, but information in open sources on these projects is either not available or not. timely updated.

15 The study does not take into account the supported international projects in the field of tourism by the EIP Karelia PPP, which are being implemented in the period 2020-2022. In the work, median indicators have been calculated.

16 Research results. In the 1990's the transformation of the socio-economic space and the change in the geopolitical position of the state in the world arena affected the nature of the interaction of the Russian Federation with neighboring countries, laying the foundation for building a qualitatively new political, economic and cultural dialogue between states on both sides of the border. In the development of the border regions of the Northwestern Federal District, the phenomenon of their involvement in European integration begins to manifest itself, when the peripheral subjects of the district become a "bridge" connecting the deep regions of the Russian Federation with European states [5]. Finland's accession to the EU in 1995 and its launching of the Northern Dimension initiative in 1997 (as an integral part of EU foreign policy) created favorable preconditions for the development of cross-border cooperation, primarily by attracting additional funds from EU programs for the implementation of cross-border projects ... Since 1995, the Northwestern Federal District has become a priority area for the TACIS Program. The implementation of international projects within the framework of TACIS has become the first and effective form of cooperation in the field of tourism with the participation of the region in the new geopolitical and economic conditions [6]. The Republic of Karelia is the only border region of the Northwestern Federal District, bordering on one state and having the longest state border with the EU in the Russian Federation (more than $700 \mathrm{~km}$, the length of the Russian-Finnish state border is $1325.8 \mathrm{~km}$ ).

17 In 1995, the European Commission approved the INTERREG-IIA-Karelia Program (1996-1999), the main focus of which in the development of cross-border cooperation was directed specifically to the Republic of Karelia. Although, according to the terms of the INTERREG Program, the activities could be implemented exclusively in Finland, the projects contributed to ${ }^{1}$ : the development of twinning relations; enhancing the development of small business; formation of a network of contacts of partners for the implementation of future projects. 
In 1998, the Government of the Republic of Karelia proposed an initiative to create the Euroregion "Karelia" (Agreement and Charter of February 24, 2000) as a new mechanism of interaction on the borders of the $E U$ and the Russian Federation. In 1997, the Republic of Karelia was included in the "territory of contiguous cooperation" of the Nordic Council of Ministers, having received financial opportunities for the development of multilateral cooperation with partners from Northern Europe (not only for the exchange of experience, but also for investment projects). In 2014, the Council was recognized as a "foreign agent" [2].

19 The second period in the development of the region's international project activities in the field of tourism (2007-2020) unites the action of two Cross-Border Cooperation Programs (CBC) Karelia. In the period 2007-2013 cooperation on the external borders of the $E U$ was carried out within the framework of the $C B C$ of the European Neighborhood and Partnership Instrument (CBC ENPI Karelia); in 2014-2020 Programs of the European Partnership Instrument (PPP EIP Karelia). The advantage of these Programs is the opportunity to participate as partners of local authorities, municipal institutions, NGOs and entrepreneurs, allowing the development of local and regional initiatives of the territories [4].

20 In total for the period 1990-2006 with the financial support of the $E U$, about 50 different international projects were implemented, directly aimed at the development of tourism in the Republic of Karelia. The largest number of them is within the framework of the TACIS Program (20 projects) and the INTERREG Program (18), $22 \%$ of the projects were supported by other sources of funding (the Nordic Council of Ministers, the Wildlife Fund, etc.). This period is characterized by the priority of consulting and technical assistance, technology transfer and training of specialists. During the period of the PPP Karelia (2007-2020), about 40 international projects aimed at developing tourism in the region were supported. Currently, within the framework of the implementation of the CAP SIP Karelia, about 15 projects have been supported (as of January 28, 2020), directly or indirectly related to the promotion of tourism in the region.

21 Involvement of the Republic of Karelia in the integration processes in the field of tourism: a municipal perspective. The study of the activity of participation of municipal districts (MR) of the Republic of Karelia in international project activities in the field of tourism makes it possible to identify the level of their involvement and the involvement of the region as a whole in integration processes.

22 Study of the average number (median) of municipalities of the Republic of Karelia involved in the implementation of international projects in the field of tourism for the period 1990-2020. for various Programs reveals a tendency of their increase from one (TACIS and INTERREG), two (other Programs, ENPI CBC Karelia) to three (CBC ENP Karelia). In addition, for the first time, within the framework of the implementation of the CBC SIP Karelia, two projects are singled out, in which all municipalities of the border region participate and can participate.

23 In total for the studied period 1990-2020, ten out of 18 municipalities in the region were the only beneficiaries of international tourism projects from the 
Russian side. At the same time, when considering projects in the previously proposed periodization, there is a decrease in the number of municipalities that are the only recipients of the effect from the implementation of tourism projects on the Russian side (Table 1.): TACIS - nine MRs, INTERREG and other Programs three MRs, ENPI PPP Karelia - two MRs, PPS EIP Karelia - there are no such municipalities.

24 Table 1Beneficiary municipalities of international tourism projects from the Russian side

\begin{tabular}{|c|c|c|c|c|}
\hline Program & TACIS & INTERREG & Other Programs & $\begin{array}{l}\text { ENPI PPP } \\
\text { Karelia }\end{array}$ \\
\hline $\begin{array}{l}\text { Municipalities of } \\
\text { the Republic of } \\
\text { Karelia (number of } \\
\text { times) }\end{array}$ & $\begin{array}{l}\text { Muezersky area (2) Petrozavodsk } \\
\text { (2) Sortavalsky area (2) } \\
\text { Lakhdenpokhsky area Loukhsky } \\
\text { area Olonetsky area Pitkyarantsky } \\
\text { area Pudozhsky area Suoyarvsky } \\
\text { area }\end{array}$ & $\begin{array}{l}\text { Petrozavodsk (6) } \\
\text { Loukhsky area (3) } \\
\text { Muezersky area }\end{array}$ & $\begin{array}{l}\text { Lakhdenpokhsky area } \\
\text { (2) Olonetsky area } \\
\text { Pudozhsky area }\end{array}$ & $\begin{array}{l}\text { Petrozavodsk } \\
\text { (6) Pryazhinsky } \\
\text { area }\end{array}$ \\
\hline
\end{tabular}

Source: compiled by the author

25 The high degree of the sole attraction of international projects in the field of tourism in the Petrozavodsk urban area is determined by the capital status of the municipality with a high concentration of scientific and educational potential and potential grantees. The next most active is the Loukhsky municipal area, which took a total part in 13 international projects, while in four it was the only beneficiary from the Russian side. Lakhdenpokhsky and Muezersky municipal areas (three projects each) occupy high positions.

26 The study of municipalities of the Republic of Karelia by the total number of international projects implemented with their participation in the field of tourism allows us to assess the level of their involvement in integration processes (Fig. 1.). Concentrating the main flows of the region, the capital's Petrozavodsk urban area is characterized by a significant excess of this indicator (participation in $56 \%$ of projects implemented in the region), therefore, this municipality is not represented in this figure. On average for the studied period 1990-2020 municipalities of the Republic of Karelia took part in the implementation of ten international projects in the field of tourism. 


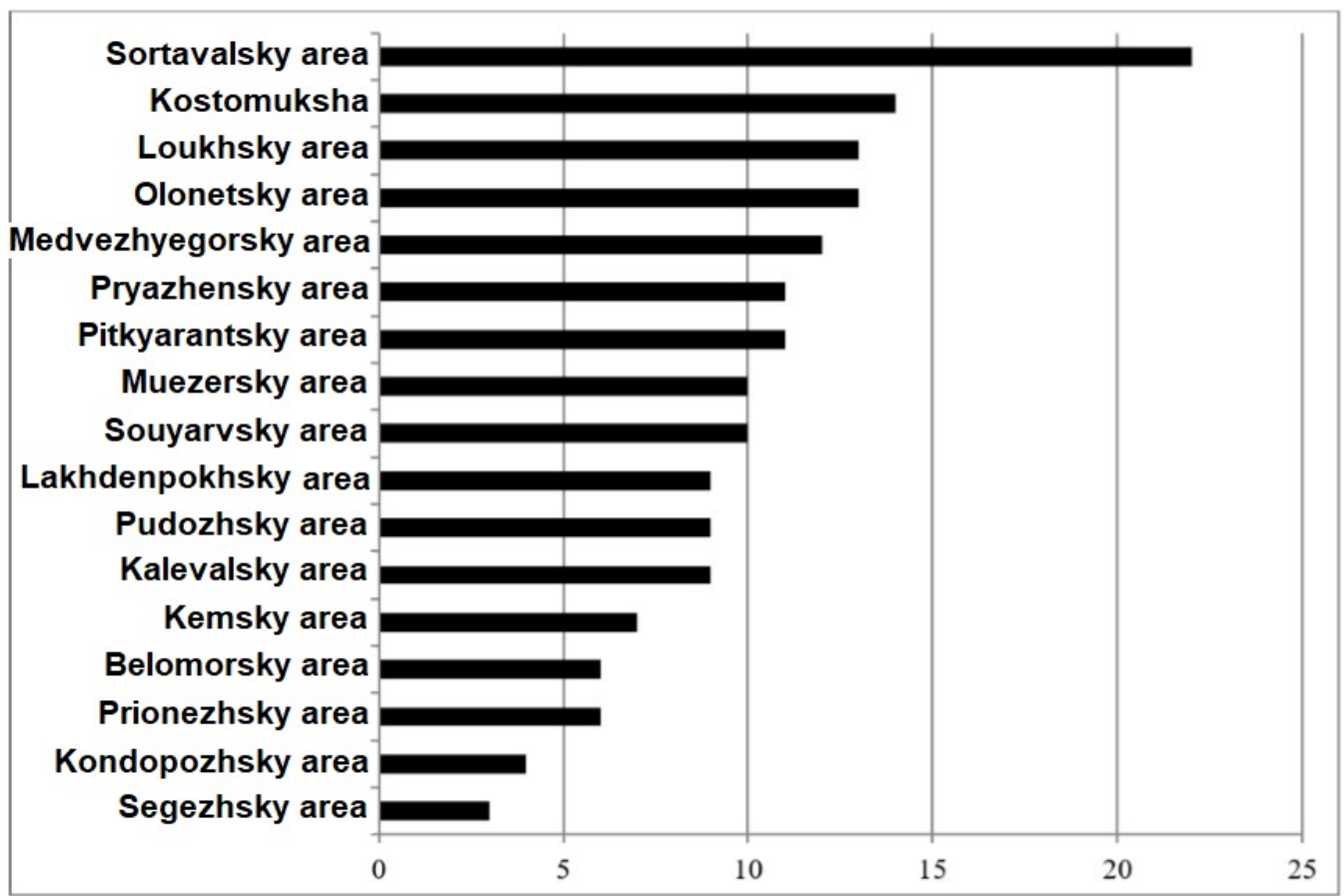

Picture 1. Distribution of municipalities of the Republic of Karelia by active participation in international project activities in the field of tourism for 19902020, number of projects (compiled by the author)

28 These facts confirm the increased activity of municipal districts in the implementation of projects and their involvement, as well as the region as a whole, in integration processes. At the same time, in contrast to the high activity, the municipalities of the Republic of Karelia stand out that did not participate in international project activities in the field of tourism during the periods of various Programs. According to the aggregate of this indicator for the studied period 19902020 these municipalities should include: Segezhsky MA (in three Programs out of the five indicated earlier); Belomorsky, Kondopozhsky, Lakhdenpokhsky and Prionezhsky MAs (in two), as well as Kalevala national, Kemsky, Muezersky, Pryazhinsky national and Pudozhsky municipal districts of the region.

$29 \quad$ The study made it possible to propose a typology of the involvement of the region's municipalities in integration processes based on aggregate quantitative indicators of the participation of territories in international tourism-oriented project activities. The following indicators have been selected as these indicators: the total number of projects, the number of times the sole benefit from the implementation of projects has been obtained, as well as the indicator of the activity of participation in the Programs (it can be positive or negative up to $\mathbf{- 5}$, based on five Programs). The paper proposes four typological groups based on the following criteria (Table 2).

30 Table 2 Criteria of typological groups for the involvement of municipalities in integration processes based on international tourism projects

\begin{tabular}{|c|c|c|c|}
\hline \multirow[t]{2}{*}{ Typological group } & $\begin{array}{l}\text { Показатели, } \\
\text { значения }\end{array}$ & & \\
\hline & $\begin{array}{l}\text { Total number of } \\
\text { projects }\end{array}$ & $\begin{array}{l}\text { Project beneficiaries from the Russian } \\
\text { Federation }\end{array}$ & $\begin{array}{l}\text { Activity of participation in the } \\
\text { Programs }\end{array}$ \\
\hline High level & $\geq 13$ & $\geq 2$ & +5 \\
\hline Average level & $11-14$ & $0-1$ & +5 \\
\hline
\end{tabular}




$\begin{array}{llll}\begin{array}{l}\text { Below the average } \\ \text { level }\end{array} & 9-11 & 0-3 & -1-2 \\ \text { Low level } & \leq 7 & 0-1 & -1-3\end{array}$

31 According to the proposed approach, the municipal districts of the Republic of Karelia are divided into typological groups as follows (Table 3).

$32 \quad$ Table 3 Typology of the involvement of municipalities of the Republic of Karelia in integration processes based on international project activities in the field of tourism

$\begin{array}{lcc}\begin{array}{l}\text { Typological group } \\ \text { High level }\end{array} & \text { No } & \begin{array}{c}\text { Municipalities } \\ \text { Petrozavodsky city district Sortovalsky area Loukhsky area Olonetsky national } \\ \text { area }\end{array} \\ \text { Average level } & 5678 & \begin{array}{c}\text { Pitkyarantsky area Souyarvsky area Kostomushsky city distruct Medvezhyegorsky } \\ \text { area }\end{array} \\ \begin{array}{l}\text { Below the average } \\ \text { level }\end{array} & 9101112 & \begin{array}{c}\text { Pryazhinsky national area Muezersky area Kalevalsky national area Pudozhsky } \\ \text { area Lakhdenpokhsky area }\end{array} \\ \text { Low level } & 141516 & \begin{array}{c}\text { Kemsky area Belomorsky area Prionezhsky area Kondopozhsky area Segezhsky } \\ \text { area }\end{array}\end{array}$

Source: compiled by the author

33 The spatially typology of the municipal districts of the Republic of Karelia in terms of involvement in integration processes is shown in Picture 2.

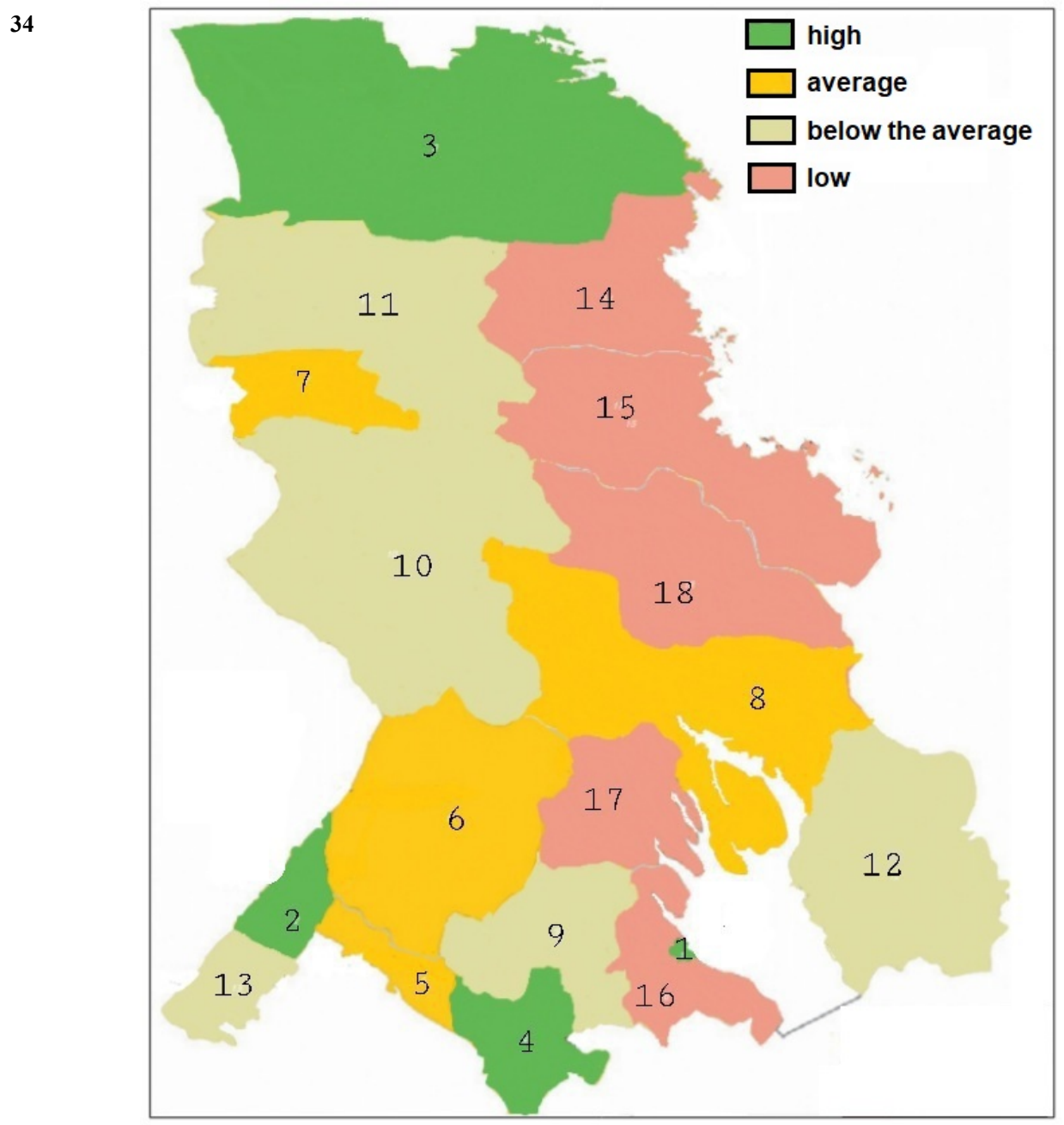

Picture 2 Typology of municipalities of the Republic of Karelia in terms of involvement in integration processes in the field of tourism based on international project activities (see Table 3; compiled by the author) 
Among the 18 municipal districts of the Republic of Karelia, four are included in the typological group with a high level of involvement in integration processes: Petrozavodsky urban area, Sortavalsky, Olonetsky national and Loukhsky areas. The high positions of the Sortavalsky municipal area, which participated in the implementation of more than 20 international tourism projects, are determined by the favorable economic and geographical position of the municipality (the presence of the Vyartsilya-Niirala checkpoint serving $74.5 \%$ or 1.5 million passengers across the Karelian section of the Russian-Finnish state border), historical aspects of the development of the Northern Ladoga area [20] and close ties at the level of border territories of neighboring states. The leading positions of the Loukhsky and Olonetsky national regions are determined by the high participation of municipalities in the implementation of international projects in the first period of 1990-2006 (eight projects each, of which, respectively, four and two are the only beneficiaries from Russia). It should be noted that these municipalities took part in the implementation of international tourism projects in all five Programs (TACIS, INTERREG, other Programs, ENPI CBC Karelia and CBC ENP Karelia).

36 The typological group of the average level of involvement includes municipalities with a fairly high activity during the period under study 1990-2020 (10-14 projects, participation in all five Programs). Almost all municipalities recorded the maximum project activity in the period 1990-2006 (excluding Kostomuksha urban area, ENPI CBC Karelia). The average level of activity in the Pitkäranta and Suojärvi districts may be due to the historical aspects of the development of the territory (as part of the Grand Duchy of Finland and independent Finland until 1940), formed by close ties at the level of border territories of neighboring states. The Kostomuksha urban area is characterized by a high level of cooperation with the border municipalities of Finland and has a Lutta - Vartius checkpoint across the Russian-Finnish state border.

37 The typological group below the average level of activity unites five municipal districts that participated in the implementation of 9-11 international projects in the field of tourism and have a pass to participate in one of the Programs (the exception is the Lahdenpoh Municipal District, which participates in two Programs). The degree of obtaining the effect as the only beneficiary from the Russian side from the implementation of the project ranges from zero to three.

38 The typological group below the average level of activity unites five municipal districts that participated in the implementation of 9-11 international projects in the field of tourism and have a pass to participate in one of the Programs (the exception is the Lakhdenpokhsky Municipal Area, which participates in two Programs). The degree of obtaining the effect as the only beneficiary from the Russian side from the implementation of the project ranges from zero to three.

39 Five other municipalities in the region were included in the group of low involvement in integration processes. They are united by their remoteness from the Russian-Finnish state border and their location along the federal highway R-21 KOLA (until 2018 M-18 St. Petersburg - Murmansk), which stretches over a 
greater length along the eastern part of the Republic of Karelia. At the same time, this typological group included two municipalities (Prionezhsky and Segezhsky municipal areas), which showed an increase in the activity of participation in international project activities in the field of tourism, starting from 2007 (PPP Karelia), in contrast to other regions of the Republic of Karelia.

40 Discussion and conclusion. The approach proposed and tested in the article makes it possible to identify qualitative changes and the dynamics of the development of cross-border cooperation of the region with neighboring states and form a comprehensive idea of the level of involvement of the region in integration processes in the municipal context based on international tourism projects. Research of international project activities of the Republic of Karelia in the field of tourism for the period 1990-2020 (about 90 projects) made it possible to identify the strengthening of the region's involvement in integration processes, which is manifested in the following changes: - in changing the sources of funding and decision-making from the $E U$ resolution to the equal participation of the Russian Federation; - in the transition from technology transfer, training and professional development of personnel to the implementation of best practices in the tourism sector, from consulting and technical assistance and the development of technical documentation to the implementation of infrastructure projects; - in the emergence of an opportunity to participate in the PPP of all municipalities in the region, and as partners of local authorities, municipal institutions, NGOs and entrepreneurs; in the growth of the activity of municipalities in the implementation of international tourist project activities.

41 The study made it possible to determine four typological groups of municipalities in the Republic of Karelia in terms of their involvement in integration processes. The high degree of participation of regions in international project activities is determined by the capital status with a high concentration of scientific and educational potential and potential grantees, the advantages of economic and geographical location, historical aspects of the development of territories, close ties at the level of border territories of neighboring states. Municipalities of the typological group of low level of involvement are united by low project activity, significant remoteness from the Russian-Finnish state border and location along the federal highway R-21 KOLA, which stretches for a greater length along the eastern part of the Republic of Karelia. Considering that international projects seem to be a unique tool that contributes to the development of territorial initiatives to activate and improve the tourism sector of activity based on the possibility of using foreign experience and attracting additional funding, the results obtained can be used to enhance the participation of the territories of the Republic of Karelia in international project activities in the field of tourism in regional and municipal level.

$42 \quad$ Further research will be aimed at identifying general trends and specifics of the implementation of international projects in terms of the formation of the transboundary tourist and recreational space "Karelia", uniting the border regions of neighboring states: the Republic of Karelia (Russia) and North Karelia (Finland). 
The material of the article has scientific and practical significance for researchers focusing on the development of regional tourism and international cooperation, municipal administrations, regional authorities, teachers and students of specialized educational institutions, as well as those interested in the development of tourism business.

\section{Примечания:}

1. Cross-border cooperation of the Republic of Karelia 1989-2000 The Official Karelia The official Internet portal of the Republic of Karelia. [Electronic resource]: URL: http://old.gov.karelia.ru/Power/Ministry

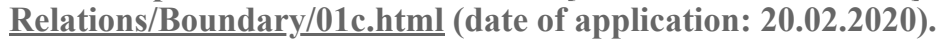

Библиография:

1. Mezhevich N. M. (2009), Cross-border cooperation and practice of Euroregions in the North-West of Russia and the Republic of Belarus, Sankt-Petersburg, 268 p. (in Russ.).

2. Border periphery of Russia: geoeconomics, communications, strategy: collective monograph (2018), Petrozavodsk, KarRC RAN, 241 p. (in Russ.).

3. Shekov V. A. (2015), Geological and mining heritage of Karelia of Finland. Cross-Border Cooperation Program ENPI CBC "Karelia" KA 334 "Mining road", Trudy Karelskogo nauchnogo centra RAN, no. 7, pp. 205-210. (in Russ.).

4. Shlapeko E. A. (2019), Republic of Karelia in cross-border cooperation projects, Oikumena, no.1, pp. 17-25. (in Russ.).

5. Shljamin V. A. (2007), Russian-Finnish economic relations. Problems and prospects, Sankt-Petersburg, 292 p. (in Russ.).

6. Shorohov E. A., Gromov V. V., Chervjakov O. V., Shljamin V. A. (2001), International experience in tourism development in the Russian part of the Barents Euro-Arctic region, Petrozavodsk. (in Russ.).

7. Bâtea (Bota) C.-M. (2014), Cross-border projects - means for sustainable tourism development along the Romanian-Hungarian border, Analele Universității din Oradea, Seria Geografie, no. 2. (December). pp. 134-142.

8. Högmander J. \& Koivunen L. Kotimäki (1999), General Plan for Ecotourism. Developmant of Ecotourism in the National park Vodlozero. Forest Resource Management in Northwest Russia: the Karelia Project FDRUS 9507, Petrozavodsk.

9. Ivanter D., Shchurov I., Shirokov V. Hiitola (2002), River as a promising object of fishing tourism (the fisheries estimations), Petrozavodsk, $47 \mathrm{p}$.

10. Kropinova E. G. (2020), The Role of Tourism in Cross-Border Region Formation in the Baltic Region, Baltic Region - The Region of Cooperation, 
Springer Proceedings in Earth and Environmental Sciences, Springer, Cham, DOI: https://doi.org/10.1007/978-3-030-14519-4 10.

11. Kropinova E. G. (2013), Cooperation between Russia and the EU in the field of innovative development of tourism: the case of the Lithuania-Poland-Russia crossborder cooperation programme, Baltic Region, no. 4 (18), pp. 48-57.

12. Land use planning, tourism and regional development in the north-west coast of Lake Ladoga and eastern Lake Saimaa area (2000), (eds.) Mikhailova N., Ieshko E., Lintunen P., Petrozavodsk, 213 p.

13. Makkonen T., Williams A., Weidenfeld A., Kaisto V. (2018), Cross-border knowledge transfer and innovation in the European neighbourhood: tourism cooperation at the Finnish-Russian border, Tourism management, vol. 68, pp. 140151. DOI: 10.1016/j.tourman.2018.03.008.

14. Manakov A. G., Golomidova E. S. (2018), Estimating the development of the Latvian-Estonian-Russian transboundary tourism and recreation region, Baltic Region, vol. 10, no. 1, pp. 130-141. DOI: 10.5922/2079-8555-2018-1-8.

15. Nenonen J. K. \& Stepanova S. V. (2018), Geological tourism development in the Finnish-Russian borderland: the case of the cross-border geological route "Mining Road", Acta Geoturistica, vol. 9, no. 1, pp. 23-29. DOI: 10.1515/agta-2018-0003.

16. Nilson J. H., Eskilsson L., Ek R. (2010), Creating cross-border destinations: Interreg Programmes and regionalization in the Baltic Sea area, Scandinavian Journal of Hospitality and Tourism, vol. 10. no. 2, pp. 153-172.

17. Palmowski T., Fedorov G. M. (2020), The potential for development of RussianPolish cross-border region, Geography, Environment, Sustainability, no. 13 (1), pp. 21-28.

18. Pysz J. K., Cargnin A. P., Lemos B., Rückert A. (2020), The Assessment of the INTERREG VA Program: Support for the Polish-Slovak Cross-Border Projects, Cross-Border Cooperation (CBC) Strategies for Sustainable Development. DOI: 10.4018/978-1-7998-2513-5.ch003.

19. Stepanova S. V. (2017), Cross-border tourist routes: the potential of Russia's North- West, Baltic Region, vol. 9, no. 4, pp. 97-112. DOI: 10.5922/2079-8555-20174-7.

20. Stepanova S. V. (2019), The Northern Ladoga region as a prospective tourist destination in the Russian-Finnish borderland: Historical, cultural, ecological and economic aspects, Geographia Polonica, vol. 92, iss. 4, pp. 409-428. DOI: https://doi.org/10.7163/Gpol.0156.

21. Stoffelen A. (2018), Tourism trails as tools for cross-border integration: A best practice case study of the Vennbahn cycling route, Annals of Tourism Research, no. 73, pp. 91-102. 
22. Studzieniecki T. (2016), The development of cross-border cooperation in an EU macroregion - a case study of the Baltic Sea Region, Procedia Economics and Finance, no. 39, pp. 235-241.

23. The attractiveness of rural tourism destinations in the Republic of Karelia and eastern Finland (2014), (eds.) S. Karhapää\& Ja. Suni, Joensuu, 81 p.

24. Więckowski M., Cerić D. (2016), Evolving tourism on the Baltic Sea coast: perspectives on change in the Polish maritime borderland, Scandinavian Journal of Hospitality and Tourism, vol. 16, iss. 1, pp. 98-111. DOI:

10.1080/15022250.2016.1244598.

25. Zaitseva N. A., Korneevets V. S., Semenova L. V. (2016), Prospects for the Cross-Border Cooperation Between Russia and Poland in the Field of Tourism, International Journal of environmental \& science education, vol. 11, no. 14, pp. $7166-7175$. 


\title{
The involvement of the region into integration processes: tourism projects (case of the Republic of Karelia)
}

\author{
Svetlana Kondrateva \\ Institute of Economics of the Karelian Research Centre of the Russian Academy of \\ Sciences \\ Russian Federation, Petrozavodsk
}

Abstract

International project activity is one of the tools for establishment of stable networks of interaction between countries, for integration of the territories of neighboring states. The article aims to determine the involvement of the region into integration processes on the basis of international tourism-oriented project activities in the municipal context. The research information base includes a vast array of information on the practice of international project activities of the Republic of Karelia in the field of tourism for the period 1990-2020 (about 90 projects under five Programs) in the context of 18 municipalities of the region. The work calculated median indicators. The study used the analysis of statistical and analytical information, content analysis of strategic documents, methods of generalization, comparison and analogies.. The author proposed an approach that allows to recognize a comprehensive vision of the level of involvement of the region in the integration processes in the municipal context as well as to formulate ecommendations for enhancing this sphere of activity. Two main periods of development of international project activities in the field of tourism in the region are defined. The typology of involvement of municipalities of the Republic of Karelia in integration processes based on aggregate indicators of project activity is proposed. The strengthening of the involvement of the Republic of Karelia as a whole and individual municipalities in the integration processes in the field of tourism is substantiated. The results of this study can be used by regional authorities when making managerial decisions in tourism area. The outcomes of the research have scientific and practical significance for scholars who research the issues of the development of regional tourism as well as for representatives of tourism business.

Keywords: international projects, the Republic of Karelia, involvement in integration processes, municipality, tourism

Date of publication: 19.05 .2021

Citation link:

Kondrateva S. The involvement of the region into integration processes: tourism projects (case of the Republic of Karelia) // Pskov Journal of Regional Studies. - 
2021. - Issue 1 (45) C. 62-76 . URL: https://prj.pskgu.ru/s221979310013150-8-1/. DOI: $10.37490 / \mathbf{S 2 2 1 9 7 9 3 1 0 0 1 3 1 5 0 - 8}$

Код пользователя: 0; Дата выгрузки: 26.04.2023; URL - http://prj.pskgu.ru/s221979310013150-8-1/ Bсе права защищены. 